\title{
Water content in arc basaltic magma in the Northeast Japan and Izu arcs: an estimate from $\mathrm{Ca} / \mathrm{Na}$ partitioning between plagioclase and melt
}

\author{
Masashi Ushioda ${ }^{1 *}$, Eiichi Takahashi ${ }^{1}$, Morihisa Hamada ${ }^{1,2}$ and Toshihiro Suzuki ${ }^{1,2}$
}

\begin{abstract}
The variation in water content of arc basaltic magmas in the Northeast Japan arc and the Izu arc was estimated using a simple plagioclase phenocryst hygrometer. In order to construct a plagioclase phenocryst hygrometer optimized for arc basalt magmas, we have conducted high-pressure melting experiments of relatively primitive basalt from the Miyakejima volcano, a frontal-arc volcano in the Izu arc. As a result of the experiments, we found that the $\mathrm{Ca} / \mathrm{Na}$ partition coefficient between plagioclase and hydrous basaltic melt increases linearly with an increase in $\mathrm{H}_{2} \mathrm{O}$ content in the melts. We then selected from literature geochemical data sets of relatively primitive basaltic rocks with no evidence of magma mixing and the most frequent Ca-rich plagioclase phenocrysts from 15 basaltic arc volcanoes including both frontal-arc and rear-arc volcanoes. In the 15 volcanoes studied, plagioclase phenocrysts of high anorthite content (An > 90) were commonly observed, whereas plagioclase phenocrysts in rear arc volcanoes usually had a lower anorthite content $(90>\mathrm{An}>80)$. In all volcanoes studied, the estimated $\mathrm{H}_{2} \mathrm{O}$ content of basaltic magma was at least 3 wt. $\% \mathrm{H}_{2} \mathrm{O}$ or higher. The magmas of volcanoes located on the volcanic front have about $5 \mathrm{wt} . \% \mathrm{H}_{2} \mathrm{O}$ in magma whereas those from the rear-arc side are slightly lower in $\mathrm{H}_{2} \mathrm{O}$ content.
\end{abstract}

Keywords: Island arc basalt; Water content; Plagioclase; Hydrous melting experiments; Across-arc geochemical variation

\section{Findings}

\section{Introduction}

Primary arc basalt magma is generated by partial melting of the sub-arc mantle with the addition of dehydrated aqueous fluid from the subducting slab. $\mathrm{H}_{2} \mathrm{O}$ has profound effects on the melting temperature of the mantle, crystallization pathways of generated magmas, and the explosivity of magmas. Therefore, magmatism in an island arc along a subduction zone is controlled by $\mathrm{H}_{2} \mathrm{O}$ released by the dehydration of a subducting slab. Precise estimation of $\mathrm{H}_{2} \mathrm{O}$ content in arc basalt magma is important for evaluating the effect of $\mathrm{H}_{2} \mathrm{O}$ on generation, differentiation, and eruption of magmas in subduction zones. However, estimation of pre-eruptive $\mathrm{H}_{2} \mathrm{O}$ content on arc magmas is difficult owing to degassing from erupting magmas.

\footnotetext{
* Correspondence: ushioda.m.ab@m.titech.ac.jp

${ }^{1}$ Magma Factory, Department of Earth and Planetary Sciences, Tokyo Institute of Technology, 2-12-1 Ookayama, Meguro-ku, Tokyo 152-8551, Japan Full list of author information is available at the end of the article
}

Sakuyama (1979) discussed lateral variation of the $\mathrm{H}_{2} \mathrm{O}$ content of basalt magmas across the Northeast Japan arc. Based on the systematic differences in phenocryst mineral assemblages in andesite and dacite and the assumption that these rocks are derived from basalt magmas by fractional crystallization, Sakuyama (1979) concluded that primary magmas from a volcanic front have a lower $\mathrm{H}_{2} \mathrm{O}$ concentration than those of a rear arc. This conclusion was further extended by Tatsumi et al. (1983) in constructing a magma genesis model for arc basalt magmas. However, this assumption is not always true because magma mixing and melting of crustal components may occur frequently to derive silicic magma. More recently, Nakamura and Iwamori (2009) estimated lateral variation of the fluid component in the source mantle based on the systematics of trace elements and isotopic compositions of arc volcanic rocks. According to their estimates, rear-arc volcanoes in central Japan are enriched in the fluid component of their mantle source, whereas the basaltic volcanoes on the volcanic front in the Izu arc are depleted in the fluid component of their source. 
In experimental research on arc basalt magmas, many studies (e.g. Sisson and Grove 1993a; Kawamoto 1996; Pichavant and Macdonald 2007; Hamada and Fujii 2008) proposed that fractional crystallization of hydrous basalts yields calc-alkaline trends whereas relatively low $\mathrm{H}_{2} \mathrm{O}$ content in basaltic magma yields tholeiitic fractionation trends. On the contrary, recent melt inclusion studies (e.g. Sisson and Layne 1993; Newman et al. 2000; Saito et al. 2005, 2010; Ikehata et al. 2010) indicated that the $\mathrm{H}_{2} \mathrm{O}$ content in tholeiitic basaltic melt is larger than 3 wt.\% at the volcanic front.

The anorthite content of plagioclase is shown to increase with an increase in $\mathrm{H}_{2} \mathrm{O}$ content of coexisting melt in all experimental studies (e.g., Johannes 1978; Sisson and Grove 1993a; Takagi et al. 2005; Hamada and Fujii 2007). Based on this relation, several plagioclase phenocryst hygrometers have been proposed (Housh and Luhr 1991; Putirka 2005; Hamada and Fujii 2007; Lange et al. 2009). High anorthite content of plagioclase phenocrysts $(\mathrm{An}>90)$ is often reported in basaltic rocks from frontal-arc volcanoes (e.g. Kimata et al. 1995; Amma-Miyasaka and Nakagawa 2002), suggesting that magmas erupting from frontal-arc volcanoes are $\mathrm{H}_{2} \mathrm{O}$ rich such as $>3$ wt.\% $\mathrm{H}_{2} \mathrm{O}$ in basaltic melt from the Izu-Oshima volcano (Hamada and Fujii 2007). A major disadvantage of the plagioclase phenocryst hygrometers proposed thus far, however, is that they can be used only when the pressure, temperature, and compositions of coexisting plagioclase and melts are known.

In this study, we conducted high-pressure and hightemperature melting experiments on arc basalt from the Miyakejima volcano at an $\mathrm{H}_{2} \mathrm{O}$-undersaturated condition and at 100 to $200 \mathrm{MPa}$, which is the pressure corresponding to a shallower crustal magma chamber. In order to discuss the variation of $\mathrm{H}_{2} \mathrm{O}$ content in arc basalts, a simple plagioclase phenocryst hygrometer is proposed. Using this simple hygrometer, the $\mathrm{H}_{2} \mathrm{O}$ content in basalt magma occurring in the Northeast Japan and Izu arcs is estimated.

\section{Methods}

\section{High-pressure and high-temperature experiments}

Starting material In order to construct a plagioclase phenocryst hygrometer for arc basalt magma, highpressure and high-temperature experiments were conducted on Ofunato scoria (OFS), which is a relatively primitive basalt from the Miyakejima volcano. Miyakejima is an active volcanic island located about $200 \mathrm{~km}$ south of Tokyo on the volcanic front of the Izu-Mariana arc. The OFS is one of the most primitive basalts to have erupted in the last 10,000 years in the Ofunato Stage 7,000 to 10,000 years ago (Tsukui et al. 2002; Niihori et al. 2003). The whole-rock composition of the OFS is as follows: 50.11 wt.\% $\mathrm{SiO}_{2}, 0.92$ wt.\% $\mathrm{TiO}_{2}, 18.09$ wt.\% $\mathrm{Al}_{2} \mathrm{O}_{3}$,
11.06 wt.\% FeO (total), 0.21 wt.\% MnO, 5.78 wt.\% $\mathrm{MgO}$, 11.78 wt.\% $\mathrm{CaO}, 1.85$ wt.\% $\mathrm{Na}_{2} \mathrm{O}, 0.22$ wt.\% $\mathrm{K}_{2} \mathrm{O}$, 0.01 wt. $\% \mathrm{P}_{2} \mathrm{O}_{5}$, and $\mathrm{Mg} \#(=\mathrm{Mg} /(\mathrm{Mg}+\mathrm{Fe}) \times 100)=48.2$, which was determined through analysis of glass fused at $1 \mathrm{~atm}$ using an electron microprobe. OFS has 0.7 vol.\% of olivine and 10.9 vol.\% of plagioclase phenocrysts in which core compositions are $\mathrm{Mg \#}=78$ to 82 and $\mathrm{An}(=\mathrm{Ca} /(\mathrm{Ca}+$ $\mathrm{Na}) \times 100)=90$ to 96 (Figure 1 ). The most frequent core composition of plagioclase phenocrysts in OFS is An94. All phenocrysts have a large clear core and a narrow normal-zoned rim with a sharp boundary. The amount of magma mixing with the evolved magma is negligible. Hydrous OFS glasses with various $\mathrm{H}_{2} \mathrm{O}$ contents were synthesized and were used as starting materials for highpressure and high-temperature melting experiments in this study (Additional file 1: Table S1).

Experimental and analytical procedures We conducted experiments at pressures of 100, 150, and $200 \mathrm{MPa}$ using SMC-2000 and SMC-5000 internally heated pressure vessels (IHPVs; Miyagi et al. 1997; Tatsumi and Suzuki 2009; Tomiya et al. 2010; Hamada et al. 2013) installed at the Magma Factory, Tokyo Institute of Technology, Tokyo, Japan. These IHPVs use argon gas as the pressurizing medium and can be pressurized up to 200 and $480 \mathrm{MPa}$, respectively. Pressure was measured by a strain-gauge pressure transducer. For SMC-2000, a single W5Re-W26Re thermocouple near the capsule was used to monitor temperature. For SMC-5000, two W5Re-W26Re thermocouples were used that were spaced $10 \mathrm{~mm}$ apart vertically; the observed temperature gradient across the capsule was less than $10^{\circ} \mathrm{C}$. Experiments were performed in the temperature and pressure ranges of $1,050^{\circ} \mathrm{C}$ to $1,150^{\circ} \mathrm{C}$ and 100 to $200 \mathrm{MPa}$, respectively. Run durations were $12 \mathrm{~h}$ for experiments at

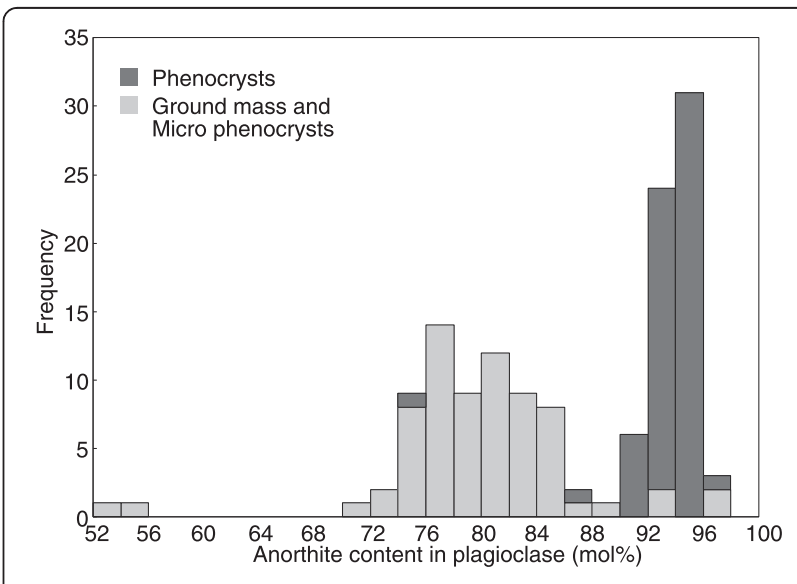

Figure 1 Frequency distribution of plagioclase compositions in phenocrysts and groundmass, in Ofunato scoria (OFS) erupted from Miyakejima volcano. The most frequent composition of plagioclase phenocrysts is $\mathrm{An}=94$. 
$1,150^{\circ} \mathrm{C}$ and $24 \mathrm{~h}$ for the other experiments. The doublecapsule method was used to buffer oxygen fugacity with a solid powder $\mathrm{Ni}-\mathrm{NiO}$ (10:1, wt.) assemblage. A metal tube with a composition of either $\mathrm{Au}_{75} \mathrm{Pd}_{25}(2.5 / 2.2 \varphi)$, $\mathrm{Au}_{75} \mathrm{Pd}_{25}(2.5 / 2.3 \varphi)$ or $\mathrm{Ag}_{50} \mathrm{Pd}_{50}(2.3 / 2.0 \varphi)$ was used as an inner sample tube that was welded on one end and weighed. Hydrous glasses synthesized at high pressure as a starting material was inserted into the inner capsule and weighed, then welded on the other end and weighed. The weight loss during welding was generally $<0.00005 \mathrm{~g}$. We also prepared a metal tube (Pt, 3.0/2.8 $\varphi$ ) that was welded on one end. $\mathrm{Ni}-\mathrm{NiO}$ powder and distilled water were then inserted into the tube, and the other end was only crimped rather than welded. Prepared sample capsules and a buffer capsule were placed into the outer capsule $\left(\mathrm{Au}_{80} \mathrm{Pd}_{20} ; 6.0 / 5.6 \varphi, \mathrm{Au}_{75} \mathrm{Pd}_{25} ; 8.0 / 7.8 \varphi\right.$ or $\mathrm{Au}_{80} \mathrm{Pd}_{20}$; $8.0 / 7.6 \varphi)$, and the outer capsule was then welded. The entire capsule was kept at $110^{\circ} \mathrm{C}$ in an oven for 20 to $30 \mathrm{~min}$ and was weighed to ensure that the seal on the capsule was effective. After each run and quenching of the products, experimental charges were weighed to measure volatile loss and were punctured to verify the presence of liquid $\mathrm{H}_{2} \mathrm{O}$. In each buffered capsule, the presence of two phases of $\mathrm{Ni}$ and $\mathrm{NiO}$ was confirmed. The phase assemblage of the run products and compositions of minerals and glass were determined by using a JEOL JXA-8530 F electron microprobe (JEOL Ltd., Tokyo, Japan) for plagioclase; JXA-8800 was used for the others. To analyze small plagioclase 5 - to $20-\mu \mathrm{m}$ long, the acceleration voltages were $10 \mathrm{kV}$ for plagioclase and $15 \mathrm{kV}$ for the other phases. The beam current and time spent on each elemental peak, except for $\mathrm{Na}$ and the background, were $12 \mathrm{nA}, 20 \mathrm{~s}$ and $10 \mathrm{~s}$, respectively. $\mathrm{Na}$ was analyzed for $10 \mathrm{~s}$ (background: 5 s) without a peak search to avoid count loss. Minerals were analyzed using a focused electron beam, whereas a defocused electron beam 10 to $15 \mu \mathrm{m}$ in diameter was employed for the glass. A loss of $\mathrm{Na}$ count was not detected for minerals and hydrous glasses during analyses. The $\mathrm{H}_{2} \mathrm{O}$ content of hydrous glass as a starting material was analyzed using a 15 to $89 \mu \mathrm{m}$ doubly polished wafer of glass and transmittance measurements of Fourier transform infrared spectroscopy (FTIR; Jasco FT/IR-6100 and IRT-5000, vacuum type, JASCO Corporation, Tokyo, Japan) with an aperture size of $100 \mu \mathrm{m}$. A Ge/KBr beam splitter and $\mathrm{HgCdTe}(\mathrm{MCT})$ detector were also used. The thicknesses of the doubly polished thin sections, 15 to $89 \mu \mathrm{m}$, were analyzed by a digital micrometer (Mitutoyo Corporation, Kanagawa, Japan) with $\pm 1 \mu$ m precision. The dispersion of sample thickness was $\pm 2 \mu \mathrm{m}$. Homogeneity of hydrous glasses was confirmed in analyses of several different points. Following the procedures of Yamashita et al. (1997), the absorbance peak heights at the $3,500 \mathrm{~cm}^{-1}$ band were used to quantify the $\mathrm{H}_{2} \mathrm{O}$ content. The density of the hydrous basaltic glass was calculated by applying the equation of Ohlhorst et al. (2001). The $\mathrm{H}_{2} \mathrm{O}$ content of the run products was analyzed by reflectance measurements using the same FTIR (Additional files 2 and 3). The calibration curve of $\mathrm{H}_{2} \mathrm{O}$ in the melt versus the $\Delta$ reflectance at peak near $3,650 \mathrm{~cm}^{-1}$, shown in Additional file 2: Figure A1, was used to estimate the $\mathrm{H}_{2} \mathrm{O}$ content in the hydrous glass in the run products.

\section{Results and discussion \\ Experimental results and proposal for a plagioclase phenocryst hygrometer}

Experimental conditions and results are listed in Table 1 and Table 2. All experiments except for C1839 were conducted near the liquidus of plagioclase ( \pm magnetite); therefore, the composition of the melt was essentially same as the starting material. Oxygen fugacity was determined for C1839 using a plagioclase-olivine oxygen fugacity barometer (Sugawara 2001). That for C1839 was conducted at a low temperature in order to crystallize mafic minerals; the estimated $\mathrm{fO}_{2}$ was $\triangle \mathrm{NNO}+0.8$. Although $\mathrm{fO}_{2}$ in the other run products was not estimated due to the lack of plausible mineral assemblages, the value would be close to that of NNO for three reasons. $\mathrm{Ni}$ and $\mathrm{NiO}$ coexisted in recovered buffer capsules in all runs, and similar $\mathrm{fO}_{2}$ was estimated in previous works using the same double-capsule technique and similar apparatus. Moreover, the FeO content of plagioclase depends on $\mathrm{fO}_{2}$ (Sugawara 2001) and the range of the $\mathrm{FeO}$ (total) content of plagioclase in all run products was narrow (1.3 \pm 0.1 wt.\%). Hamada and Fujii (2007, 2008) conducted high-pressure, high-temperature experiments using the double-capsule method with the $\mathrm{NNO}+\mathrm{H}_{2} \mathrm{O}$ buffer and an internally heated pressure vessel (IHPV) apparatus similar to SMC-5000 at the University of Tokyo. Hamada and Fujii (2007) estimated that the $\mathrm{fO}_{2}$ condition was $\triangle \mathrm{NNO}+0.8$ to 2.0 by using the Co-Pd alloy redox sensor technique (Taylor et al. 1992), and Hamada and Fujii (2008) estimated that $\mathrm{fO}_{2}$ was $\Delta \mathrm{NNO}+1$ $( \pm 0.8)$ by using the oxygen barometer of Sugawara (2001). We conducted experiments for a shorter duration (12 h) at $1,150^{\circ} \mathrm{C}$ compared to $24 \mathrm{~h}$ in the others in order to minimize the loss of diffusive $\mathrm{H}_{2}$ from the capsule assemblage. Plagioclase was euhedral and rectangular and up to $15 \mu \mathrm{m}$. Magnetite was up to $10 \mu \mathrm{m}$ in diameter. Both minerals were uniform in composition throughout the recovered run products, indicating that equilibrium was achieved. The $\mathrm{H}_{2} \mathrm{O}$ content of the melt was calculated by mass balance calculation of all phases assuming that water was concentrated in only the melt. The $\mathrm{H}_{2} \mathrm{O}$ content in the melt in run products relatively poor in crystals was measured by the reflectance infrared (IR) method (Additional files 2 and 3); the results agreed with mass balance calculations (Table 1). Figure 2a shows the relation between $\mathrm{H}_{2} \mathrm{O}$ content in the melt and the anorthite 
Table 1 Experimental conditions and results

\begin{tabular}{|c|c|c|c|c|c|c|c|c|c|c|c|c|}
\hline Run\# & Capsule\# & $\begin{array}{c}\text { Run } \\
\text { durations (h) }\end{array}$ & $\mathrm{T}\left({ }^{\circ} \mathrm{C}\right)$ & $\begin{array}{l}\text { Pressure } \\
\text { (MPa) }\end{array}$ & $\begin{array}{c}\text { Bulk } \mathrm{H}_{2} \mathrm{O} \\
\text { (wt.\%) }^{\mathrm{a}}\end{array}$ & $\begin{array}{c}\mathrm{H}_{2} \mathrm{O} \text { in melt } \\
(\text { wt.\% } \%)^{b}\end{array}$ & $\begin{array}{c}\mathrm{H}_{2} \mathrm{O} \text { in melt } \\
(\text { wt.\% } \%)^{\mathrm{c}}\end{array}$ & $\begin{array}{l}\text { Phase and modal } \\
\text { proportions (wt.\%) }\end{array}$ & $\begin{array}{c}\text { Calculated } \\
\mathrm{fO}_{2}(\Delta \mathrm{NNO})^{\mathrm{e}}\end{array}$ & $\begin{array}{c}\text { Relative } \\
\text { Fe-loss (wt.\%) }\end{array}$ & $K_{\mathrm{D}}^{\text {pl-melt }}{ }_{\mathrm{Ca}-\mathrm{Na}}$ & $\begin{array}{c}\text { An in } \\
\text { plagioclase }\end{array}$ \\
\hline HG442 & C1838 & 12 & 1,150 & 100 & $0.77(3)$ & $0.91(10)$ & & Melt (85), pl (15) & & -13 & $1.05(17)$ & 80.4 \\
\hline HG442 & C1837 & 12 & 1,150 & 100 & $2.07(9)$ & $2.11(13)$ & $2.01(19)$ & Melt (98), pl (2) & & -6 & $2.21(27)$ & 88.4 \\
\hline G463 & C1831 & 24 & 1,100 & 100 & $2.99(12)$ & $3.23(17)$ & $3.00(25)$ & Melt (93), pl (5), mt (2) & & 0 & $3.14(31)$ & 91.3 \\
\hline G459 & C1824 & 12 & 1,150 & 150 & $0.77(3)$ & $0.91(10)$ & & Melt (85), pl (15) & & -11 & $0.93(10)$ & 76.9 \\
\hline G459 & C1820 & 12 & 1,150 & 150 & $1.57(11)$ & $1.71(16)$ & $1.52(14)$ & Melt (92), pl (8) & & -8 & $1.56(19)$ & 84.7 \\
\hline G458 & C1817 & 24 & 1,100 & 150 & $2.59(9)$ & $2.92(10)$ & & Melt (88), pl (10), mt (2) & & -3 & $2.36(33)$ & 88.8 \\
\hline HG448 & C1857 & 24 & 1,075 & 150 & $2.99(12)$ & $3.44(13)$ & & Melt (87), pl (10), mt (3) & & 1 & $2.78(26)$ & 90.2 \\
\hline G465 & C1839 & 24 & 1,100 & 200 & $0.77(3)$ & $1.24(11)$ & & Melt (62), pl (32), ol (3), cpx (1), opx (2) & 0.8 & -14 & $1.06(23)$ & 79.4 \\
\hline G465 & C1840 & 24 & 1,100 & 200 & $2.07(9)$ & $2.42(10)$ & & Melt (86), pl (12), mt (3) & & 5 & $2.11(28)$ & 87.7 \\
\hline G465 & C1841 & 24 & 1,100 & 200 & $2.99(12)$ & $3.16(13)$ & $3.16(27)$ & Melt (95), pl (3), mt (2) & & 6 & $2.42(26)$ & 89.9 \\
\hline
\end{tabular}

${ }^{\mathrm{a}} \mathrm{H}_{2} \mathrm{O}$ content of starting materials analyzed by transmittance measurements using Fourier transform infrared spectroscopy (FTIR). Standard deviation is indicated in parentheses; ${ }^{\mathrm{b}} \mathrm{H}_{2} \mathrm{O}$ in melt calculated from mass balance. Standard deviation is indicated by parentheses; ${ }^{c} \mathrm{H}_{2} \mathrm{O}$ in melt analyzed by $\Delta$ reflectance measurements using FTIR. Standard deviation is indicated in parentheses; ${ }^{d}$ phase proportion in weight percent indicated by parentheses.

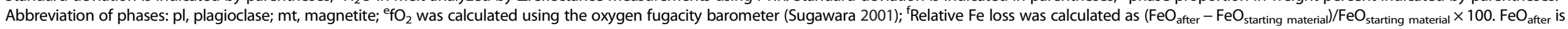
the summation of $\mathrm{FeO}$ (total $\mathrm{Fe}$ as $\mathrm{FeO}$ ) from all phase in run products. 
Table 2 Volcanoes which were estimated by Equation 1

\begin{tabular}{|c|c|c|c|c|c|c|c|c|}
\hline Volcano & Reference & $\begin{array}{c}\text { Sample } \\
\text { name }\end{array}$ & $\begin{array}{c}\text { An } \\
\text { content }\end{array}$ & Mode & $\begin{array}{c}\mathrm{CaO} / \mathrm{Na}_{2} \mathrm{O} \\
\text { (bulk) }\end{array}$ & $\begin{array}{c}\mathrm{Al}_{2} \mathrm{O}_{3} / \mathrm{SiO}_{2} \\
\text { (bulk) }\end{array}$ & $K_{\mathrm{D}}^{\text {pl-melt }}{ }_{\text {Ca-Na }}$ & $\begin{array}{c}\text { Estimated } \\
\mathrm{H}_{2} \mathrm{O} \\
\end{array}$ \\
\hline Towada & Hunter and Blake (1995) & Zak13 & 91 to 94 & 92.5 & 4.71 & 0.36 & 4.74 & 5.6 \\
\hline Iwate $^{a}$ & Kuritani et al. (2014a) & VIW-18 & 85 to 92 & 92 & 6.11 & 0.36 & 3.41 & 3.9 \\
\hline Funagata $^{a}$ & Fujinawa (1982) & Type1 & 94.8 & & 7.65 & 0.32 & 4.31 & 5.1 \\
\hline Zao & Tatsumi et al. (2008) & Za1013 & 80 to 96 & 92 & 4.94 & 0.35 & 4.21 & 5.0 \\
\hline Adatara & Fujinawa (1988; 1990) & $2-1$ & 78 to 95 & 90 & 4.10 & 0.39 & 3.98 & 4.7 \\
\hline Nasu (Minami-Gassan) & Ban (1991) & E-1 101408 & 86 to 92 & 89 & 4.58 & 0.35 & 3.20 & 3.7 \\
\hline Myoko & Sakuyama (1981) & MK278-4 & 80 to 94 & 88 & 3.65 & 0.36 & 3.63 & 4.2 \\
\hline Ueno & Nakano $(1993,1994)$ & SKS-3 & 82 to 87 & 87 & 3.81 & 0.31 & 3.18 & 3.7 \\
\hline Fuji & Kaneko et al. (2010) & FG1013 & 64 to 92 & 88 & 4.17 & 0.36 & 2.66 & 3.1 \\
\hline \multirow[t]{2}{*}{ East-Izu } & Kawamoto (1992) & Uchino & 84 to 88 & 86 & 3.27 & 0.36 & 4.06 & 4.8 \\
\hline & Kikuchi and Takahashi (2004) & Takatsukayama, scoria1-2 & 84 to 88 & 87 & 3.84 & 0.37 & 2.53 & 3.7 \\
\hline Izu-Oshima & Ikehata et al. (2010) & O95 & 88 to 90 & 89 & 6.42 & 0.34 & 2.28 & 2.6 \\
\hline Niijima & Koyaguchi (1986) & WAK-10 & 71 to 92 & 91 & 4.28 & 0.34 & 4.28 & 5.1 \\
\hline \multirow[t]{2}{*}{ Miyakejima } & This study & OFS & 90 to 96 & 94 & 6.37 & 0.36 & 4.45 & 5.3 \\
\hline & Amma-Miyasaka et al. (2005) & $S-1$ & 53 to 97 & 87 & 4.68 & 0.35 & 2.59 & 3.0 \\
\hline Hachijo-Higashiyama & Tsukui et al. (1993) & Nakanohana scoria & 85 to 93 & 92 & 8.60 & 0.37 & 2.42 & 2.7 \\
\hline Sumisu-caldera & Tamura et al. (2005) & D2-R4 & 80 to 90 & 90 & 5.92 & 0.34 & 2.75 & 3.2 \\
\hline Torishima $^{a}$ & Tamura et al. (2007) & OP 35 & 95.9 & & 10.15 & 0.37 & 4.17 & 4.9 \\
\hline
\end{tabular}

${ }^{a}$ Reference had no frequency distribution of plagioclase phenocryst compositions.

content of plagioclase in our run products. In the range of experimental conditions, the anorthite content of plagioclase positively correlated with the $\mathrm{H}_{2} \mathrm{O}$ content in melt. As shown in Figure 2a, $K_{\mathrm{D} \text { pl-melt }}^{\mathrm{Ca}}\left(=(\mathrm{Ca} / \mathrm{Na})_{\mathrm{pl}} /(\mathrm{Ca} /\right.$ $\mathrm{Na})_{\text {melt }}$ ) was proportional to the $\mathrm{H}_{2} \mathrm{O}$ content in the melt (Figure $2 \mathrm{~b}$ ), and the effects of temperature and pressure were not significant. A simple plagioclase hygrometer is expressed as a linear function as

$$
\begin{aligned}
& K_{\mathrm{D}}^{\mathrm{Ca}-\mathrm{Na}}=0.74 \mathrm{X}_{\mathrm{H}_{2} \mathrm{O}}(\text { wt. } .) \times 100+0.36 \\
& R^{2}=0.917 \quad \text { Standard error }=0.23
\end{aligned}
$$
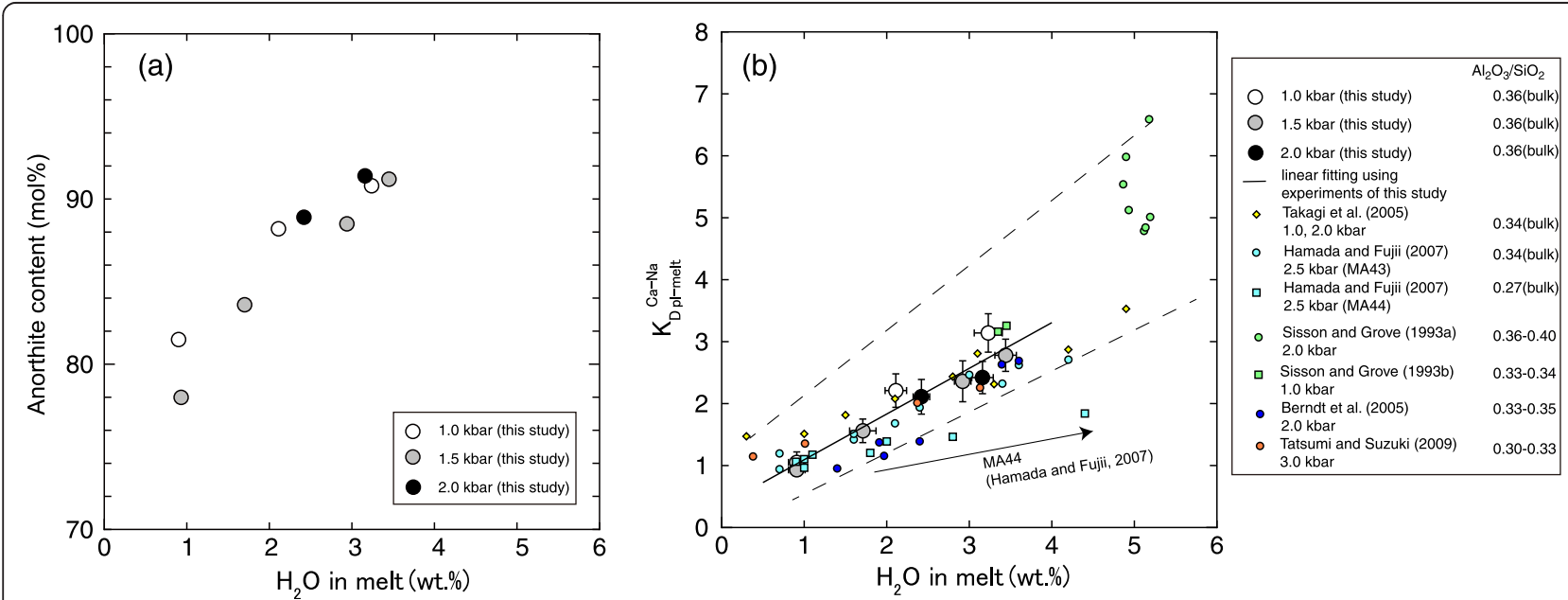

Figure 2 Relation between $\mathrm{H}_{2} \mathrm{O}$ concentration in melt and (a) anorthite content of coexisting near-liquidus plagioclase or (b) $K_{\mathrm{D} \text { pl-melt }}^{\mathrm{Ca}}$. At 1.0, 1.5, and $2.0 \mathrm{kbar}$. (b) Dashed lines represent the range in typical basalt from the Northeast Japan and Izu $\operatorname{arcs}\left(0.32<\mathrm{Al}_{2} \mathrm{O}_{3} / \mathrm{SiO}_{2}<0.39\right)$. When the $\mathrm{H}_{2} \mathrm{O}$ content was estimated by Equation 1, the expected error was within that indicated by the dashed lines. Source: Berndt et al. (2005) and Sisson TW et al. 1993b. 
Strictly speaking, this equation is applicable for only arc basalts with compositions and pressure and temperature conditions similar to those in the present experiments. According to Hamada and Fujii (2007), $K_{\mathrm{D} \text { pl-melt }}^{\mathrm{Ca}-\mathrm{Na}}$ depends strongly on the $\mathrm{Al}_{2} \mathrm{O}_{3} / \mathrm{SiO}_{2}$ ratio of the melt. In order to check the effect of the melt composition on $K_{\mathrm{D} \text { pl-melt }}^{\mathrm{Ca}-\mathrm{Na}}$, previous experimental data obtained at 100 to $300 \mathrm{MPa}$ with various ratios of $\mathrm{Al}_{2} \mathrm{O}_{3} / \mathrm{SiO}_{2}$ of basaltic melt were compiled, as shown in Figure 2b. Most previous experiments were conducted with melts in limited ranges of $\mathrm{Al}_{2} \mathrm{O}_{3} / \mathrm{SiO}_{2}$ ratio $\left(\mathrm{Al}_{2} \mathrm{O}_{3} / \mathrm{SiO}_{2}=0.31\right.$ to 0.39). Lower $\mathrm{Al}_{2} \mathrm{O}_{3} / \mathrm{SiO}_{2}(=0.27)$ experiments (MA44) by Hamada and Fujii (2007) show significantly lower $K_{\mathrm{D} \text { pl-melt }}^{\mathrm{Ca}-\mathrm{Na}}$ than that in other experiments. If Equation 1 was applied to estimate the $\mathrm{H}_{2} \mathrm{O}$ content in relatively primitive arc basalts $\left(\mathrm{Al}_{2} \mathrm{O}_{3} / \mathrm{SiO}_{2}=\right.$ 0.31 to 0.39 ; Table 2), the error of the plagioclase phenocryst hygrometer would be approximately \pm 1 wt. $\% \mathrm{H}_{2} \mathrm{O}$ (Figure 2b).

Contrary to the effect of dissolved $\mathrm{H}_{2} \mathrm{O}$ in the melt, crystallized plagioclase becomes sodic with increasing pressure at a given melt composition (e.g. Takagi et al. 2005). Takagi et al. (2005) determined experimentally that anorthite-rich plagioclase $(\mathrm{An}>90)$ phenocrysts can be crystallized at only a shallow-level crustal magma chamber (200 to $300 \mathrm{MPa}$ ) with 5 to 6 wt.\% dissolved $\mathrm{H}_{2} \mathrm{O}$ in the melt. Because $\mathrm{H}_{2} \mathrm{O}$ solubility depends strongly on pressure, magma chambers that crystallize anorthiterich plagioclase should not be too shallow. Therefore, we assume that the typical pressure is $200 \mathrm{MPa}$ for anorthiterich plagioclase phenocrysts in arc basaltic rocks. This assumption is supported by geophysical imaging of magma chambers beneath the Northeast Japan and the Izu arc volcanoes (e.g. Mikada et al. 1997; Murakami et al. 2001). In our experimental study, high-An plagioclase (An =94) was not crystallized because the high $\mathrm{H}_{2} \mathrm{O}$ content in the melt depressed the liquidus temperature of the plagioclase. Thus, the origin of highly Ca-rich plagioclase phenocrysts needs further experimental study.

In Equation 1, $K_{\mathrm{D} \text { pl-melt }}^{\mathrm{Ca} \text {-Na }}$ was expressed as a function of only $\mathrm{H}_{2} \mathrm{O}$ in the melt without regard to temperature and pressure. The present hygrometer can be applicable to arc basalt magmas under pressure and temperature conditions at least similar to those in present experiments (100 to $200 \mathrm{MPa}, 1,075^{\circ} \mathrm{C}$ to $1,150^{\circ} \mathrm{C}$ ). Our starting material was slightly higher in $\mathrm{Al}_{2} \mathrm{O}_{3}$ than basaltic magmas from the Izu-Oshima volcano without plagioclase accumulation (Nakano and Yamamoto 1991). Nevertheless, our calibration can be applicable to arc basalts in a broad sense. Hamada and Fujii (2007) suggested that the $\mathrm{Ca} / \mathrm{Na}$ partition between plagioclase and the melt depends on the $\mathrm{Al}_{2} \mathrm{O}_{3} / \mathrm{SiO}_{2}$ ratio. We estimated the error of Equation 1 at \pm 1 wt. $\%$ by comparison with previous experimental data in terms of $\mathrm{Al}_{2} \mathrm{O}_{3} / \mathrm{SiO}_{2}$ ratios; the range of arc basalts listed in Table 2 is 0.31 to 0.39 .

\section{Comparison to other hygrometers}

Plagioclase phenocryst hygrometers have been proposed by many authors (Housh and Luhr 1991; Putirka 2005; Hamada and Fujii 2007; Lange et al. 2009). The results calculated by our simple hygrometer were compared with those by other hygrometers using experimental melting study data of arc basalts (see Figure 3 and Additional file 4: Table S2).

Calculation results using Equation 1 were generally higher than those reported by Lange et al. (2009). In particular, the discrepancy was large for low $\mathrm{H}_{2} \mathrm{O}$ content. On the contrary, results using Putirka's calculations (2005) were similar to those with Equation 1. Furthermore, in order to examine various basaltic compositions, the calculated water contents based on Equation 1, Lange et al. (2009) and Putirka (2005) for previous experimental studies on alkali basalt, mid-ocean ridge basalt (MORB) and arc basalt are compared in Additional file 5: Table S3. For this calculation, experimental pressure and temperature conditions and the compositions of melt and plagioclase of the reported values were used. It is important to note that the calculated $\mathrm{H}_{2} \mathrm{O}$ contents estimated by Equation 1 show good agreement ( \pm 1 wt.\% $\mathrm{H}_{2} \mathrm{O}$ ) with experimental values. The agreement is particularly good for low to medium $\mathrm{K}$ tholeiitic basalt, (i.e., those of Izu-Oshima (Hamada and Fujii 2007) and Iwate volcanoes (Takagi et al. 2005)). Considering the alkali

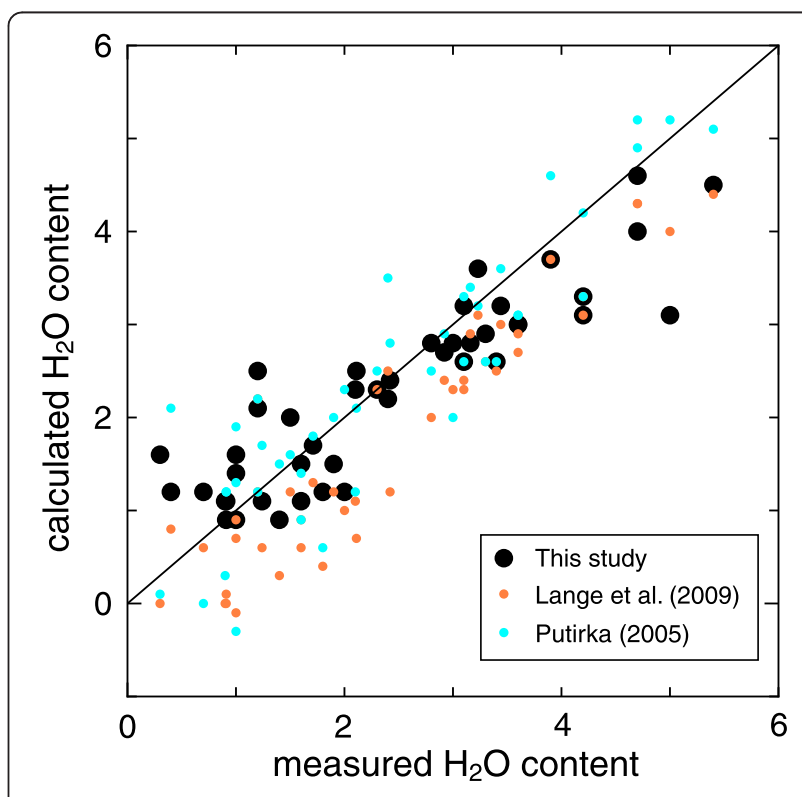

Figure 3 Relation between measured $\mathrm{H}_{2} \mathrm{O}$ content in It and calculated $\mathrm{H}_{2} \mathrm{O}$ content using hygrometers. Hygrometers used are of this and previous studies listed. Experimental data that was plotted in this figure is listed in Additional file 5: Table S3. 
dependency noted by Honma (2012), Equation 1 may be less reliable for alkali basalts. As demonstrated in Figure 3, our simple hygrometer is useful for estimating the water content in natural magma, although its application is limited in melt composition and pressure and temperature conditions for the crystallization of arc basalts.

\section{Pre-eruptive $\mathrm{H}_{2} \mathrm{O}$ content in arc basalt magmas}

Procedure of estimation of water content in arc basalt magma We used the bulk rock composition as the melt composition to be in equilibrium with the high-An plagioclase. Although bulk rock compositions generally do not represent melt compositions towing to selective phenocryst accumulation, trial calculations utilizing groundmass composition as the melt composition resulted in aberrant $\mathrm{H}_{2} \mathrm{O}$ estimation of the melt and, therefore, selected the bulk rock composition to calculate the equilibrium $\mathrm{H}_{2} \mathrm{O}$ contents of relatively primitive arc basalt magmas using Equation 1. The following discrimination rules in choosing samples were adopted: 1) Samples should come from volcanoes that have erupted basalt $\left(\mathrm{SiO}_{2}<53\right.$ wt.\%); 2) among the basalt products, the frequency of plagioclase phenocryst composition is known and shows a unimodal compositional spectrum (Figure 1); 3) we selected the least fractionated rock that satisfies the first two constraints from each volcano peak composition of plagioclase phenocryst for the estimation of $\mathrm{H}_{2} \mathrm{O}$ content of arc basaltic magma. If magma mixing occurred, estimation of melt composition that was equilibrated with plagioclase phenocrysts is difficult. Therefore, basalt without evidence of magma mixing had to be selected. According to Sakuyama (1981), the plagioclase composition frequency diagram is the best indicator for judging the occurrence of magma mixing.

Pre-eruptive $\mathrm{H}_{2} \mathrm{O}$ content of arc basalt magma The estimated $\mathrm{H}_{2} \mathrm{O}$ content of the basalt magma beneath each volcano is listed in Table 2. In magmas erupting from frontal-arc volcanoes, anorthite-rich plagioclase phenocrysts $(A n>90)$ are commonly found. On the contrary, plagioclase phenocryst tends to be slightly sodic $($ An $<90)$ in magmas erupting from rear-arc volcanoes. We estimated the $\mathrm{H}_{2} \mathrm{O}$ content of arc basalt magma using the most frequent composition of plagioclase phenocrysts using Equation 1 (Figure 4). The estimated $\mathrm{H}_{2} \mathrm{O}$ content of arc basalt magmas is in the range of 3 to $5 \mathrm{wt} . \%$ at both frontal-arc and rear-arc volcanoes. In the rear-arc region, the $\mathrm{H}_{2} \mathrm{O}$ content was estimated in only four volcanoes (Myoko, Ueno, Fuji, and Niijima); therefore, systematic differences between volcanoes in a volcanic front and those in a rear arc with regard to pre-eruptive $\mathrm{H}_{2} \mathrm{O}$ content were difficult to assess.

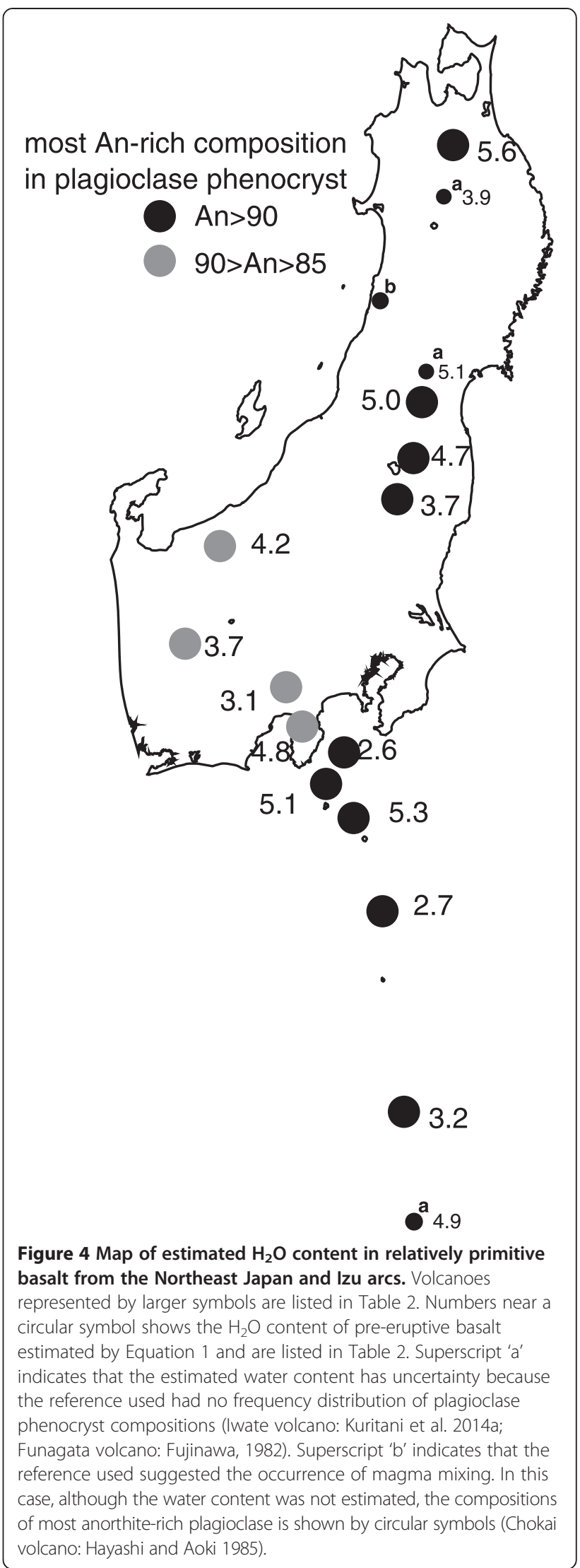


In some volcanoes, $\mathrm{H}_{2} \mathrm{O}$ content in basaltic magma was estimated by melt inclusion analysis. In the case of the Fuji volcano, Yasuda (2011) analyzed melt inclusions of olivine phenocrysts in the Fuji products and estimated the $\mathrm{H}_{2} \mathrm{O}$ content was 3.8 wt.\%. Products of Takatsukayama and Sukumoyama volcanoes located in the Higashi-Izu monogenetic volcano field contain up to $3.4 \mathrm{wt} . \% \mathrm{H}_{2} \mathrm{O}$ in olivine phenocrysts (Nichols et al. 2012). In the case of Izu-Oshima volcano, the maximum $\mathrm{H}_{2} \mathrm{O}$ content of melt inclusions in the olivine phenocrysts was $3.4 \mathrm{wt} . \%$ by analysis of products of the older Oshima group (Ikehata et al. 2010). In the case of Miyakejima volcano, Saito et al. $(2005,2010)$ analyzed melt inclusions of plagioclase and olivine phenocrysts from the AD 2000 eruption and estimated the $\mathrm{H}_{2} \mathrm{O}$ content to be 3.3 wt.\% in olivine-hosted melt inclusions. These analyses are consistent with the values of pre-eruptive $\mathrm{H}_{2} \mathrm{O}$ content in melt estimated in this study.

Kuritani et al. (2014a) estimated the $\mathrm{H}_{2} \mathrm{O}$ content of relatively primitive basalt ( $8.87 \mathrm{wt} . \% \mathrm{MgO}$ ) located at the volcanic front in Iwate volcano to be 4 to $5 \mathrm{wt}$ \% based on petrologic study. Rose-Koga et al. (2014) also analyzed olivine-hosted melt inclusions from the AD 1686 products in Iwate volcano to determine a maximum $\mathrm{H}_{2} \mathrm{O}$ content of 3.65 wt.\%. These results are consistent with our new estimate. In the case of Sannomegata volcano, which is a rear-arc volcano in the Northeast Japan arc, Kuritani et al. (2014b) estimated the $\mathrm{H}_{2} \mathrm{O}$ content of primitive basalt and source mantle and estimated $\mathrm{H}_{2} \mathrm{O}$ content to be 6 to $7 \mathrm{wt} . \%$ in the primary melt. Their estimation is based on a magma genesis model with several assumptions. In contrast, our estimates of the pre-eruptive $\mathrm{H}_{2} \mathrm{O}$ content are based on simple observation on plagioclase phenocrysts. The discrepancy between these studies can be a key issue for understanding magma differentiation processes from the upper mantle to the surface and is a topic for future investigation. Kimura and Yoshida (2006) and Kimura et al. (2010) analyzed trace element and isotope compositions of basalts in the Northeast Japan arc and the Izu-Mariana arc, respectively, and estimated the composition of primary melt, the amount of added aqueous fluid, and the $\mathrm{H}_{2} \mathrm{O}$ content in primary melt based on forward modeling of magma genesis in a subduction zone. Their estimations of $\mathrm{H}_{2} \mathrm{O}$ content in primary melts based on forward modeling are generally accordance with our estimates based on plagioclase phenocryst compositions. Sakuyama (1979) proposed across-arc lateral variation in $\mathrm{H}_{2} \mathrm{O}$ content of basalt magma in the Northeast Japan arc based on systematic differences in phenocryst mineral assemblage in evolved rocks. This theory, such that magmas in the rear-arc are more enriched in $\mathrm{H}_{2} \mathrm{O}$ than those along the volcanic front was supported by Uto (1986) and Kawamoto (1996) based on systematic changes in $\mathrm{Al}_{2} \mathrm{O}_{3}$ content during fractionation. Contrary to previous belief, our observation showed that volcanoes on a volcanic front erupt the most $\mathrm{H}_{2} \mathrm{O}$-rich basalt magma (3 to 5 wt.\%; Figure 4) or there is no measurable across arc difference in the water content of basalt magmas. In a detail study at Miyakejima volcano (Ushioda 2014), we showed that the water content in differentiated magmas strongly depends on the presence or absence of shallow-level magma chambers in a volcano. Therefore, comparison of phenocryst mineral assemblages in differentiated rocks (Sakuyama 1979) or that of the $\mathrm{Al}_{2} \mathrm{O}_{3}$ content among fractionation trends (Uto 1986; Kawamoto 1996) does not necessarily represent differences in water content in parental basalt magmas.

In other arc magmas, the $\mathrm{H}_{2} \mathrm{O}$ content has been estimated by analysis of melt inclusions. For example, in the case of the Kamchatka arc, Portnyagin et al. (2007) indicated that primitive melts in a volcanic front contain an $\mathrm{H}_{2} \mathrm{O}$ content equal to or slightly higher than those in a rear-arc. Similarly, arc basaltic melts along the Central American Volcanic Arc (Walker et al. 2003; Sadofsky et al. 2008) and the Michoacan-Guanajuato Volcanic Field of Central Mexico (Johnson et al. 2009) have slightly higher $\mathrm{H}_{2} \mathrm{O}$ content in a volcanic front.

In subduction zones, volcanoes along the volcanic front produce the largest volume of magmas, and those from volcanoes along the rear-arc produce significantly less (Sugimura et al. 1963). Therefore, the fact that basaltic magma in a volcano on the volcanic front is $\mathrm{H}_{2} \mathrm{O}$ rich has fundamental importance in the consideration of mass flux of $\mathrm{H}_{2} \mathrm{O}$ in subduction zones. Magma genesis models in subduction zones (e.g., Tatsumi et al. 1983) that assume nearly dry melting conditions beneath the volcanic front need to be reconsidered. Lateral variation of the fluid component in the source mantle based on the systematics of trace elements and isotopes reported by Nakamura and Iwamori (2009) may need reconsideration and revision since they show very small fluid addition in some volcanoes on the volcanic front.

\section{Conclusions}

In order to estimate the variation of $\mathrm{H}_{2} \mathrm{O}$ content in relatively primitive basalt in the Northeast Japan and the Izu arcs, we constructed a simple plagioclase phenocryst hygrometer applicable for temperature and pressure of shallow crustal magma chamber beneath arc volcanoes. The $\mathrm{H}_{2} \mathrm{O}$ content in representative basaltic rocks from 15 volcanoes in eastern Japan was estimated using our newly constructed simple hygrometer. High anorthite $($ An $>90)$ plagioclase phenocrysts were shown to be common in volcanoes along volcanic front whereas those along the rear arc were slightly lower (An > 80). We conclude that volcanoes on the volcanic front generally erupt $\mathrm{H}_{2} \mathrm{O}$-rich basalt magma (3 to 5 wt.\%). As was suggested by Sakuyama (1979), across-arc variation in 
$\mathrm{H}_{2} \mathrm{O}$ content of basaltic magmas is not valid for preeruptive $\mathrm{H}_{2} \mathrm{O}$ content of basaltic magmas inferred from plagioclase-melt equilibria.

\section{Additional files}

Additional file 1: Table S1. Synthesized conditions of hydrous Ofunato scoria (OFS) glasses as starting materials under non-buffered conditions. $\mathrm{H}_{2} \mathrm{O}$ content of hydrous glasses was analyzed by Fourier transform infrared spectroscopy (FTIR) with transmitted light.

Additional file 2: Calibration line for reflectance infrared (IR) method. Figure A1 and Figure A2 are included. Source: Yasuda (2014).

Additional file 3: Table S4. Experimental conditions for reflectance infrared (IR) method.

Additional file 4: Table S2. Analyzed compositions of each phase in recovered run products. Using an electron probe microanalyzer (EPMA). Fe content is given as $\mathrm{FeO}^{*}$ (total iron).

Additional file 5: Table S3. Comparison of the simple hygrometer (Equation 1) with previous hygrometers. Source: Parman et al. (2011).

\section{Competing interests}

The authors declare that they have no competing interests.

\section{Authors' contributions}

MU conducted the experimental petrological studies and drafted the manuscript. ET conceived of the study, participated in the design of the study, and contributed to drafting of the manuscript. MH participated in its design and coordination and contributed to drafting of the manuscript. TS contributed to performing the high-pressure experiments. All authors read and approved the final manuscript.

\section{Acknowledgements}

We thank Dr. Kenji Niihori for his helpful advice in collecting primitive basalt (Ofunato scoria) at Miyakejima volcano. This work was supported by MEXT Grant-in-Aid, Nos. 21109004 and 25247088 to ET. MU thanks the Global COE program 'From the Earth to Earths' for financial support as RA. We are indebted to Dr. Tatsuhiko Kawamoto, Professor Hiroaki Sato and anonymous reviewers for constructive discussions and comments for improving this manuscripts.

\section{Author details}

'Magma Factory, Department of Earth and Planetary Sciences, Tokyo Institute of Technology, 2-12-1 Ookayama, Meguro-ku, Tokyo 152-8551, Japan. ${ }^{2}$ Department of Solid Earth Geochemistry, Japan Agency for Marine-Earth Science and Technology, 2-15 Natsushima-cho, Yokosuka 237-0061, Japan.

Received: 13 December 2013 Accepted: 15 September 2014 Published: 29 September 2014

\section{References}

Amma-Miyasaka M, Nakagawa M (2002) Origin of anorthite and olivine megacrysts in island-arc tholeiites: petrological study of 1940 and 1962 ejecta from Miyake-jima volcano, Izu-Mariana arc. J Volcanol Geotherm Res 117:263-283

Amma-Miyasaka M, Nakagawa M, Nakada S (2005) Magma plumbing system of the 2000 eruption of Miyakejima Volcano, Japan. Bull Volcanol 67:354-467. doi:10.1007/s00445-004-0408-0

Ban M (1991) A petrological model for the Minamigassan Volcano, Nasu Volcanoes, Northeast Japan Arc. Bull Volcanol Soc Jpn 36(2):255-267

Berndt J, Koepke J, Holtz F (2005) An experimental investigation of the influence of water and oxygen fugacity on differentiation of MORB at $200 \mathrm{MPa}$. J Petrol 46(1):135-167. doi:10.1093/petrology/egh066

Fujinawa A (1982) Early stage crystallization differentiation of the island arc tholeiite magma, Nasu volcanic zone, Northeast Japan. J Min Petr Econ Geol 77:419-437

Fujinawa A (1988) Tholeiitic and calc-alkaline magma series at Adatara volcano, northeast Japan: 1. Geochemical constraints on their origin. Lithos 22:135-158
Fujinawa A (1990) Tholeiitic and calc-alkaline magma series at Adatara volcano, Northeast Japan: 2. Mineralogy and phase relations. Lithos 24:217-236

Hamada M, Fujii T (2007) $\mathrm{H}_{2} \mathrm{O}$-rich island arc low-K tholeiite magma inferred from Ca-rich plagioclase-melt inclusion equilibria. Geochem J 41:437-461

Hamada M, Fujii T (2008) Experimental constraints on the effects of pressure and $\mathrm{H}_{2} \mathrm{O}$ on the fractional crystallization of high-Mg island arc basalt. Contrib Mineral Petrol 155:767-790

Hamada M, Ushioda M, Fujii T, Takahashi E (2013) Hydrogen concentration in plagioclase as a hygrometer of arc basaltic melts: approaches from melt inclusion analyses and hydrous melting experiments. Earth Planet Sci Lett 365:253-262

Hayashi S, Aoki K (1985) Petrology of Chokai volcano, northeastern Japan. Part IIMineral chemistry. J Min Petr Econ Geol 80:73-82

Honma U (2012) Hydrous and anhydrous melting experiments of an alkali basalt and a transitional tholeiite from Oginosen volcano, Southwest Japan: the possible influence of melt depolymerization on $\mathrm{Ca}-\mathrm{Na}$ partitioning between plagioclase and the melt. J Miner Petrol Sci 107:8-32. doi:10.2465/ jmps.091126

Housh TB, Luhr JF (1991) Plagioclase-melt equilibria in hydrous systems. Am Mineral 76:477-492

Hunter AG, Blake S (1995) Petrogenetic revolution of a transitional tholeiitic-calcalkaline series: Towada volcano, Japan. J Petrol 36(6):1579-1605

Ikehata K, Yasuda A, Notsu K (2010) The geochemistry of volatile species in melt inclusions and sulfide minerals from Izu-Oshima volcano, Japan. Miner Petrol 99:143-152. doi:10.1007/s00710-009-0086-x

Johannes W (1978) Melting of plagioclase in the system Ab-An- $\mathrm{H}_{2} \mathrm{O}$ and Qz-AbAn- $\mathrm{H} 2 \mathrm{O}$ at $\mathrm{P}_{\mathrm{H} 2 \mathrm{O}}=5 \mathrm{kbars}$, an equilibrium problem. Contrib Mineral Petrol 66:295-303

Johnson ER, Wallace PJ, Delgado Granados H, Manea VC, Kent AJR, Bindeman IN, Donegan CS (2009) Subduction-related volatile recycling and magma generation beneath Central Mexico: insights from melt inclusions, oxygen isotopes and geodynamic models. J Petrol 50(9):1729-2764. doi:10.1093/ petrology/egp051

Kaneko T, Yasuda A, Fujii T, Yoshimoto M (2010) Crypto-magma chambers beneath Mt. Fuji. J Volcanol Geotherm Res 193:161-170

Kawamoto T (1992) Dusty and honeycomb plagioclase: indicators of processes in the Uchino stratified magma chamber, Izu Peninsula, Japan. J Volcanol Geotherm Res 49:191-208

Kawamoto T (1996) Experimental constraints on differentiation and $\mathrm{H}_{2} \mathrm{O}$ abundance of calc-alkaline magmas. Earth Planet Sci Lett 144:577-589

Kikuchi K, Takahashi M (2004) Petrology for volcanic rocks produced by nearly contemporaneous eruptions of aligned volcanic centers in the Higashi-Izu Monogenetic Volcano Group, central Japan. Proc Inst Nat Sci Nihon Univ 39:217-246

Kimata M, Nishida N, Shimizu M, Saito S, Matsui T, Arakawa Y (1995) Anorthite megacrysts from island arc tholeiite. Mineral Mag 59:1-14

Kimura J, Yoshida T (2006) Contributions of slab fluid, mantle wedge and crust to the origin of Quaternary lavas in the NE Japan Arc. J Petrol 47(11):2185-2232. doi:10.1093/petrology/egl041

Kimura J, Kent AJR, Rowe MC, Katakuse M, Nakano F, Hacker BR, van Keken PE, Kawabata H, Stern RJ (2010) Origin of cross-chain geochemical variation in Quaternary lavas from the northern Izu arc: using a quantitative mass balance approach to identify mantle sources and mantle wedge processes. Geochem Geophys Geosyst 11(10):15. doi:10.1029/2010GC003050

Koyaguchi T (1986) Evidence for two-stage mixing in magmatic inclusions and rhyolitic lava domes on Niijima island, Japan. J Volcanol Geotherm Res 29:71-98

Kuritani T, Yoshida T, Kimura J, Hirahara Y, Takahashi T (2014a) Water content of primitive low-K tholeiitic basalt magma from Iwate Volcano, NE Japan arc: implications for differentiation mechanism of frontal-arc basalt magmas. Miner Petrol 108:1-11. doi:10.1007/s00710-013-0278-2

Kuritani T, Yoshida T, Kimura J, Takahashi T, Hirahara Y, Miyazaki T, Senda R, Chang Q, Ito Y (2014b) Primary melt from Sannome-gata volcano, NE Japan arc: constraints on generation conditions of rear-arc magmas. Contrib Minera Petrol 167:969. doi:10.1007/s00410-014-0969-7

Lange RA, Frey HM, Hector J (2009) A thermodynamic model for the plagioclaseliquid hygrometer/thermometer. Am Mineral 94:494-506

Mikada H, Watanabe H, Sakashita S (1997) Evidence for subsurface magma bodies beneath Izu-Oshima volcano inferred from a seismic scattering analysis and possible interpretation of the magma plumbing system of the 1986 eruptive activity. Phys Earth Planet In 104:257-269 
Miyagi I, Yurimoto H, Takahashi E (1997) Water solubility in albite-orthoclase join and JR-1 rhyolite melts at $1000^{\circ} \mathrm{C}$ and 500 to 2000 bars, determined by micro-analysis with SIMS. Geochem J 31:57-61

Murakami M, Ozawa S, Nishimura T, Tada T (2001) A model of magma movements associated with the 2000 eruption of Usu volcano inferred by crustal deformation detected by continuous GPS and other geodetic measurements. J Geogr Surv Inst 95:99-105 (in Japanese)

Nakamura H, Iwamori H (2009) Contribution of slab-fluid in arc magmas beneath the Japan arcs. Gondwana Res 16(3-4):431-445

Nakano S (1993) Ueno basaltic rocks I: heterogeneous magmas at two monogenetic volcanoes. J Min Petr Econ Geol 88:272-288

Nakano S (1994) Ueno basaltic rocks II: chemical variation in the Kiso province, to the south of the Ontake volcano. J Min Petr Econ Geol 89:115-130

Nakano S, Yamamoto T (1991) Chemical variations of magmas at IzU-Oshima volcano, Japan: plagioclase-controlled and differentiated magmas. Bull Volcanol 53:112-120

Newman S, Stolper E, Stern R (2000) $\mathrm{H}_{2} \mathrm{O}$ and $\mathrm{CO}_{2}$ in magmas from the Mariana arc and back arc system. Geochem Geophys Geosyst 1(5):27. doi:10.1029/ 1999GC000027

Nichols ARL, Wysoczanski RJ, Tani K, Tamura Y, Baker JA, Tatsumi Y (2012) Melt inclusions reveal geochemical cross-arc variations and diversity within magma chambers feeding the Higashi-Izu Monogenic Volcano Field, Izu Peninsula, Japan. Geochem Geophys Geosyst 13(9), Q09012. doi:10.1029/ 2012GC004222

Niihori K, Tsukui M, Kawanabe Y (2003) Evolution of magma and magma plumbing system of Miyakejima volcano in the last 10,000 years. Bull Volcanol Soc Jpn 48(5):387-405

Ohlhorst S, Behrens H, Holtz F (2001) Compositional dependence of molar absorptivities of near-infrared $\mathrm{OH}$ - and $\mathrm{H}_{2} \mathrm{O}$ bands in rhyolitic to basaltic glasses. Chem Geol 174:5-20

Parman SW, Grove TL, Kelley KA, Plank T (2011) Along-arc variations in the pre-eruptive $\mathrm{H}_{2} \mathrm{O}$ contents of Mariana arc magmas inferred from fractionation paths. J Petrol 52(2):257-278. doi:10.1093/petrology/egq079

Pichavant M, Macdonald R (2007) Crystallization of primitive basaltic magmas at crustal pressures and genesis of the calc-alkaline igneous suite: experimental evidence from St Vincent, Lesser Antilles arc. Contrib Mineral Petrol 154:535-558. doi:10.1007/s00410-007-0208-6

Portnyagin M, Hoernle K, Plechov P, Mironov N, Khubunaya S (2007) Constraints on mantle melting and composition and nature of slab components in volcanic arcs from volatiles $\left(\mathrm{H}_{2} \mathrm{O}, \mathrm{S}, \mathrm{Cl}, \mathrm{F}\right)$ and trace elements in melt inclusions from the Kamchatka Arc. Earth Planet Sci Lett 255:53-69. doi:10.1016/j.epsl.2006.12.005

Putirka KD (2005) Igneous thermometers and barometers based on plagioclase + liquid equilibria: tests of some existing models and new calibrations. Am Mineral 90:336-356

Rose-Koga EF, Koga KT, Hamada M, Helouis T, Whitehouse MJ, Shimizu N (2014) Volatile ( $\mathrm{F}$ and $\mathrm{Cl}$ ) concentrations in Iwate olivine-hosted melt inclusions indicating low-temperature subduction. Earth Planets Space 66:81

Sadofsky SJ, Portnyagin M, Hoernle K, van den Bogaard P (2008) Subduction cycling of volatiles and trace elements through the Central American volcanic arc: evidence from melt inclusions. Contrib Mineral Petrol 155:433-456. doi:10.1007/s00410-007-0251-3

Saito G, Uto K, Kazahaya K, Shinohara H, Kawanabe Y, Satoh H (2005) Petrological characteristics and volatile content of magma from the 2000 eruption of Miyakejima volcano, Japan. Bull Volcanol 67:268-280

Saito G, Morishita Y, Shinohara H (2010) Magma plumbing system of the 2000 eruption of Miyakejima volcano, Japan deduced from volatile and major component contents of olivine-hosted melt inclusions. J Geophys Res 115, B11202. doi:10.1029/2010JB007433

Sakuyama M (1979) Lateral variations of $\mathrm{H}_{2} \mathrm{O}$ contents in quaternary magmas of northeastern Japan. Earth Planet Sci Lett 43:103-111

Sakuyama M (1981) Petrological study of the Myoko and Kurohime volcanoes, Japan: crystallization sequence and evidence for magma mixing. J Petrol 22(4):553-583

Sisson TW, Grove TL (1993a) Experimental investigations of the role of $\mathrm{H}_{2} \mathrm{O}$ in calc-alkaline differentiation and subduction zone magmatism. Contrib Mineral Petrol 113:143-166

Sisson TW, Grove TL (1993b) Temperatures and $\mathrm{H}_{2} \mathrm{O}$ contents of low-MgO highalumina basalts. Contrib Mineral Petrol 113:167-184

Sisson TW, Layne GD (1993) $\mathrm{H}_{2} \mathrm{O}$ in basalt and basaltic andesite glass inclusions from four subduction-related volcanoes. Earth Planet Sci Lett 117:619-635
Sugawara T (2001) Ferric iron partitioning between plagioclase and silicate liquid: thermodynamics and petrological applications. Contrib Mineral Petrol 141:659-686. doi:10.1007/s004100100267

Sugimura A, Matsuda T, Chinzei K, Nakamura K (1963) Quantitative distribution of late Cenozoic volcanic materials in Japan. Bull Volcanol 26:125-140

Takagi D, Sato H, Nakagawa M (2005) Experimental study of a low-alkali tholeiite at 1-5 kbar: optimal condition for the crystallization of high-An plagioclase in hydrous arc tholeiite. Contrib Mineral Petrol 149:527-540. doi:10.1007/ s00410-005-0666-7

Tamura Y, Tani K, Ishizuka O, Chang Q, Shukuno H, Fiske RS (2005) Are arc basalts dry, wet, or both? Evidence from the Sumisu Caldera Volcano, Izu-Bonin Arc, Japan. J Petrol 46(9):1769-1803. doi:10.1093/petrology/egi033

Tamura Y, Tani K, Chang Q, Shukuno H, Kawabata H, Ishizuka O, Fiske RS (2007) Wet and dry basalt magma evolution at Torishima volcano, Izu-Bonin arc, Japan: the possible role of phengite in the downgoing slab. J Petrol 48(10):1999-2031. doi:10.1093/petrology/egm048

Tatsumi Y, Suzuki T (2009) Tholeiitic vs calc-alkalic differentiation and evolution of arc crust: constraints from melting experiments on a basalt from the Izu-Bonin-Mariana arc. J Petrol 50(6):1575-1603. doi:10.1093/petrology/egp044

Tatsumi Y, Sakuyama M, Fukuyama H, Kushiro I (1983) Generation of arc basalt magmas and thermal structure of the mantle wedge in subduction zones. J Geophys Res 88(B7):5815-5825. doi:10.1029/JB088iB07p05815

Tatsumi Y, Takahashi T, Hirahara Y, Chang Q, Miyazaki T, Kimura J-I, Ban M, Sakayori A (2008) New insights into andesite genesis: the role of mantlederived calc-alkalic and crust-derived tholeiitic melts in magma differentiation beneath Zao Volcano, NE Japan. J Petrol 49(11):1971-2008. doi:10.1093/ petrology/egn055

Taylor JR, Wall VJ, Pownceby MI (1992) The calibration and application of accurate redox sensors. Am Mineral 77:284-295

Tomiya A, Takahashi E, Furukawa N, Suzuki T (2010) Depth and evolution of a silicic magma chamber: melting experiments on a low-K rhyolite from Usu volcano, Japan. J Petrol 51(6):1333-1354. doi:10.1093/petrology/egq021

Tsukui M, Suzuki M, Sano A (1993) Evolution of magma plumbing system of Hachijo-Higashiyama volcano in the last 30,000 years. Bull Volcanol Soc Jpn 38(6):199-212

Tsukui M, Niihroi K, Kawanabe Y (2002) The 2000 AD subsidence caldera at Miyakejima volcano, Izu arc, Japan. Bull Earth Res Inst Univ Tokyo 77:27-42

Ushioda M (2014) Experimental study on evolution of arc basaltic magma chamber: case study on Miyakejima volcano. Ph.D. Thesis. Tokyo Institute of Technology, Japan

Uto K (1986) Variation of $\mathrm{Al}_{2} \mathrm{O}_{3}$ content in late Cenozoic Japanese basalts: a re-examination of Kuno's high-alumina basalt. J Volcanol Geotherm Res 29:397-411

Walker JA, Roggensack K, Patino LC, Cameron BI, Marias O (2003) The water and trace element contents of melt inclusions across an active subduction zone. Contrib Mineral Petrol 146:62-77. doi:10.1007/s00410-003-0482-x

Yamashita S, Kitamura T, Kusakabe M (1997) Infrared spectroscopy of hydrous glasses of arc magma compositions. Geochem J 31:169-174

Yasuda A (2011) FT-IR micro reflectance measurements of water content in melt inclusions. Bull Volcanol Soc Jpn 56(2-3):41-49

Yasuda A (2014) A new technique using FT-IR micro-reflectance spectroscopy for measurement of water concentrations in melt inclusions. Earth Planets Space 66:34. doi:10.1186/1880-5981-66-34

doi:10.1186/1880-5981-66-127

Cite this article as: Ushioda et al:: Water content in arc basaltic magma

in the Northeast Japan and Izu arcs: an estimate from $\mathrm{Ca} / \mathrm{Na}$

partitioning between plagioclase and melt. Earth, Planets and Space $201466: 127$. 